\title{
THE BATTLE OF ALGIERS AT FIFTY: END OF EMPIRE CINEMA AND THE FIRST BANLIEUE FILM
}

\section{Alan O’Leary}

La bataille d'Alger (The Battle of Algiers, Gillo Pontecorvo), which premiered at the Venice Film Festival on September 3, I966, has turned fifty. In itself, this fact is trivial; after all, a great many films are reaching their half-century mark these days. The difference is that The Battle of Algiers - an ItalianAlgerian co-production commissioned by the Algerians themselves as a hymn to their achievement of independence from France in I962 - seems to reach far beyond cinema itself to attain an "endlessly renewed contemporary resonance." I The re-release of Battle in 2004 was marked by ruminations and polemics regarding the film's argument for urban terrorism in the service of national liberation. ${ }^{2}$ Commentators put a new emphasis on the film's picturing of Islam, a dimension of Battle that seemed to require comment in the light of September I I, 200I. ${ }^{3}$ Today, attacks inspired or directed by ISIS seem to ensure that the film and its sympathetic version of "Islamic" violence retain a controversial visibility. ${ }^{4}$ At the same time, the film's presentation of the "rational" argument made by the French military for the use of torture as a means to gather intelligence speaks to Battle's ambivalence about its anticolonial theme. ${ }^{5}$

Let it be said immediately that discourses situating Battle in relation to contemporary Islamist or Islamist-inspired violence partake of an old-fashioned Orientalism that posits a clash of civilizations, homogenizes North Africa and the Middle East in terms of a "pan-Arab terrorism," and obscures the history of Western occupation as itself terroristic (whether as the direct violence of oppression or as the structural violence of racial hierarchies and economic exploitation). ${ }^{6}$ But such discourse is also of a piece with the negative reception of Battle that dates back to its original premiere at the Venice film festival, when the French delegation walked out in protest. $^{7}$ Subsequent denunciation was as loud from the left as from the right, with the

Film Quarterly, Vol. 70, Number 2, pp. 17-29, ISSN 0015-1386, electronic ISSN 1533-8630. (c) 2016 by The Regents of the University of California. All rights reserved. Please direct all requests for permission to photocopy or reproduce article content through the University of California Press's Reprints and Permissions web page, http://www. ucpress.edu/journals.php?p=reprints. DOI: 10.1525/FQ.2016.70.2.17. former dismissing the film's "objectivity" — that is, its presentation of the human cost to both sides and its refusal to demonize even the torturers - as a sop to bourgeois sensibility. ${ }^{8}$ In fact, any film dealing with the ugly circumstances of political violence will inevitably generate debate and controversy, but it is valid to ask whether, apart from its relevance to world affairs, there is anything left to say about Battle today. ${ }^{9}$

Its fiftieth anniversary offers an occasion to challenge some of the commonplaces about the film and to show that there remains much to be clarified about its character. An attention to location in the film and a focus on its littlediscussed coda can resituate Battle as a film that, going beyond its well-recognized revolutionary narrative, deals with the end of the French empire and represents the first in a line of banlieue cinema-that is, as a film that presciently anticipates postcolonial conditions on the territory of France itself.

\section{End of Empire Cinema}

As archival material related to Battle becomes more readily available, several commonplaces about the film can be interrogated or discarded now, on the tenth anniversary of Gillo Pontecorvo's death. Consider an illustrated press release from the archive at Turin's Museo del Cinema dedicated to Pontecorvo. ${ }^{\text {Io }}$ Apparently produced to support the distribution of Battle in the United States, the press release asserts that "the realism achieved by director Pontecorvo is accomplished by using the actual Casbah locations and residents as well as a cast that is almost entirely nonprofessional." These terms_realism, nonprofessional actors, Casbah location, even the auteurist focus on the director himself-remain today the default lexicon in discussions of Battle, obscuring important aspects of the film. The emphasis on the intentionality and creative will of its director disguises the extent to which the film was the expression of anticolonial sentiment worldwide: Battle took the form it did in order to reach and address both national and international audiences. ${ }^{\text {I I }}$ 
The realism of the film is an aspect of this address. Famously, Pontecorvo and cinematographer Marcello Gatti chose to employ a deliberately degraded black and white film stock that so convincingly recalls newsreel photography that the American distributor had to add a title stating that "NOT ONE FOOT of newsreel or documentary film has been used."12 The mimicry of documentary footage was designed to give the impression of viewing evidence, of witnessing events as they occur, just as the use of unknown faces, "nonprofessionals," was intended to give an impression of authenticity. As Nancy Virtue recalls, "in debates over historical accuracy The Battle of Algiers has alternately been praised for its realistic depiction of historical events and taken to task for departing from, omitting or distorting historical fact." ${ }^{\text {"3 }}$ The realism is part of the film's rhetoric, an aspect of its emotive power and the vehicle of its historical argument; yet this documentary realism has often been presented instead as a "value" that the film itself has sometimes been criticized for failing to sustain.

The tropes that persist in discussions of Battle have discouraged deeper investigation into its multivalent character. Battle is regularly placed in the tradition of neorealist cinema as exemplified by Roberto Rossellini's Roma città aperta (Rome Open City, 1945) and Paisà (Paisan, 1946), which both treated the final months of World War II and looked forward to democratic renewal in Italy after the experience of fascism and war, just as Battle looked forward to the consolidation of Algerian independence. ${ }^{\mathrm{I}}{ }^{4}$ However, Battle is at the same time what might be called an "end of empire" film, a film that deals with the exhaustion of the French and European imperial project. While the label "empire cinema" has typically been used to refer to films about the British empire, Ruth Ben-Ghiat has importantly repurposed it to refer to Italian films on imperial themes (by Rossellini, among others) made between 1936, when Mussolini declared the Italian empire, and 1943, when fascist Italy collapsed. ${ }^{15}$ Ben-Ghiat and others have shown that questions of realism and the overlap between documentary and fiction were key to the modes of fascist empire cinema and to discourse around them. Realism was employed to provide the Italian colonial project with a seductive "rhetoric of anti-rhetoric." The realist idiom allowed empire cinema to express the ideology of the regime in the guise of documentary truth and facilitated the address of three diverse audiences: Italians themselves, the colonized populations, and the wider international community. ${ }^{16}$

Realism and the overlap between documentary and fiction are very much the terms in which Battle has regularly been debated, legitimated, or criticized. And it is striking that the film's celebration of the birth of the Algerian nation is couched in a mode-documentary realism - that has an earlier source in the colonial cinema of fascism than the democratic cinema of postwar neorealism to which it is usually traced. ${ }^{17}$ Theories and practices of realism in the context of fascist imperialism anticipate and influence postwar Italian neorealism, which has therefore been inaccurately presented as a rebirth or "return" to realism after the "lies" of fascism. ${ }^{18}$ Marie-France Courriol has written that Italian empire films were intended to offer "vivid descriptions of the colonial reality" and that they "operated a contextualization of an imperialist project that had to emerge as a natural historical result." ${ }^{19}$ This description of the fascist imperial cinema is remarkably apt as well for the end of empire Battle, in which a vivid description of colonial reality generates the sense that anticolonial desire and national liberation will emerge as historical inevitabilities. Thus the empire cinema's address to multiple audiences anticipates the complex operation performed by Battle in speaking to and for the new Algerian nation, managing the difficult balance of remaining palatable in the colonizing North even as it was appealing to anticolonial sentiment internationally. ${ }^{20}$

\section{On Location}

The Turin archive's press release asserted that Battle was made "using actual Casbah locations" and scholarship has tended to follow its line, emphasizing the representation of the Casbah to the exclusion of other spaces in the film. Scholars have eagerly invested in the Casbah as the authentic space of indigeneity and resistance, a correspondence encouraged in Battle itself as a dichotomy between European city and Casbah, expressed in a pan-and-zoom shot six minutes into the film. Even Guy Austin confidently asserts that Battle is "set in the Casbah of Algiers." 2 This is not wrong, but it is insufficient: Battle is not set only in the Casbah. Indeed, drawings included with the original press release render scenes from the film set neither in the Casbah nor in the so-called European city but rather in a new housing project, the Climat de France, on the periphery of the city.

The spatial dichotomy between Casbah and European city that the film initially posits is a narrative expedient, in part, whereby the tale of two cities can figure the relationship of colonizer and colonized throughout Algeria and throughout the colonized world, exemplifying what Frantz Fanon called the "colonial world cut in two." ${ }^{.22}$ But it also points to how Battle had to reckon with powerful tropes inherited from earlier cinema: the Maghrebi colonial city as it was imagined in Casablanca (Michael Curtiz, I942), for example, 

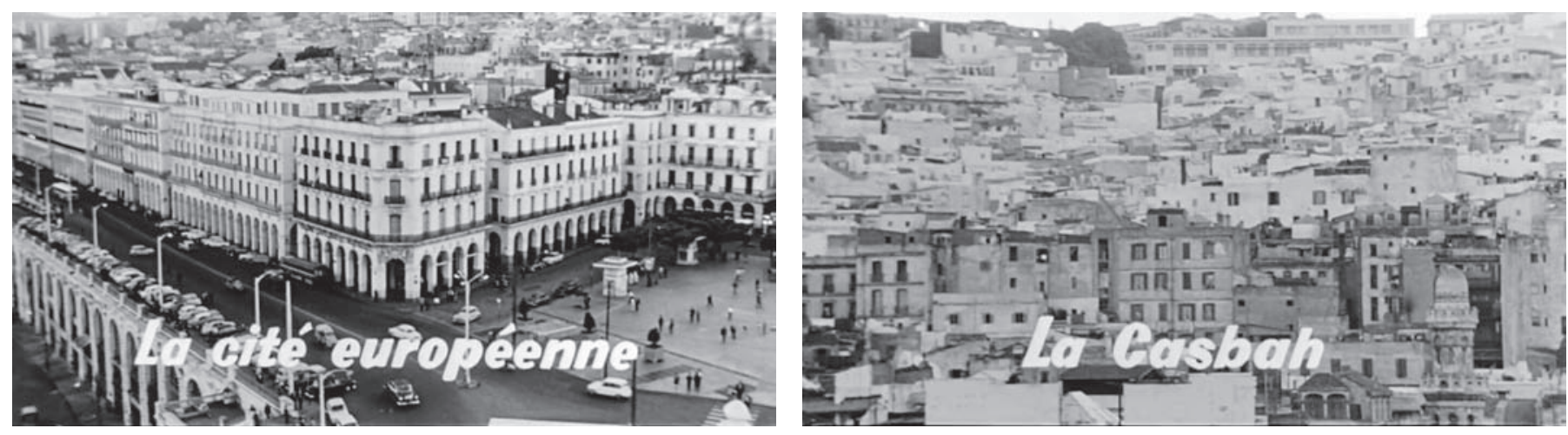

The European city and the Casbah are presented as polar opposites that define Algiers.

with its cast of opportunists, refugees, and predatory locals, or more pertinently, in Pépé le Moko (Julien Duvivier, 1937). As Mary Jean Green has shown, Battle is replete with allusions to the 1937 film (as was Casablanca), in which Jean Gabin plays the charismatic titular gangster who makes the Algerian Casbah his domain, with a few scenes filmed on location in Algiers itself. ${ }^{23}$ The Casbah in Pépé le Moko is described in voiceover as a "teeming anthill," an unpoliceable labyrinth of transgression populated from a rogues' gallery of "traditionalist Barbarians ... Kabyles, Chinese, Gypsies, stateless people, Slavs, Maltese, negroes, Sicilians, Spaniards ... [and prostitutes,] girls of all nations, shapes, and sizes."

An early sequence in Battle opposes this inherited version of the Casbah by asserting it as a "moral" space, instead, as the Front de Libération Nationale (the FLN, or National Liberation Front) banishes drunkenness, drug use, and prostitution; the sequence ends with a dignified Muslim marriage ceremony in a Casbah interior. But Battle also "cleans up" the Casbah ethnically, making it into an exclusively Arab and Muslim space that is uniform, temperate, and authentic, as counterposed to a European city characterized by its leisure spaces. ${ }^{24}$

The opposition between European city and Casbah is a means to efficiently narrate the story while making the argument for anticolonial struggle in terms that are legible at home and abroad. ${ }^{25}$ As such, it also points to the film's address to the wider world on behalf of the FLN and new Algerian nation-state. ${ }^{26}$ But in failing to account for spaces in the film that are neither European city nor Casbah, Battle scholarship shows itself to have been seduced by the film's own rhetoric. The hybrid, third spaces that appear in the film's remarkable six-minute coda are key to its status as an "end of French empire" film. The new housing projects of Algiers that are glimpsed in the coda anticipate the banlieue districts which will grow up outside city perimeters in France in the period

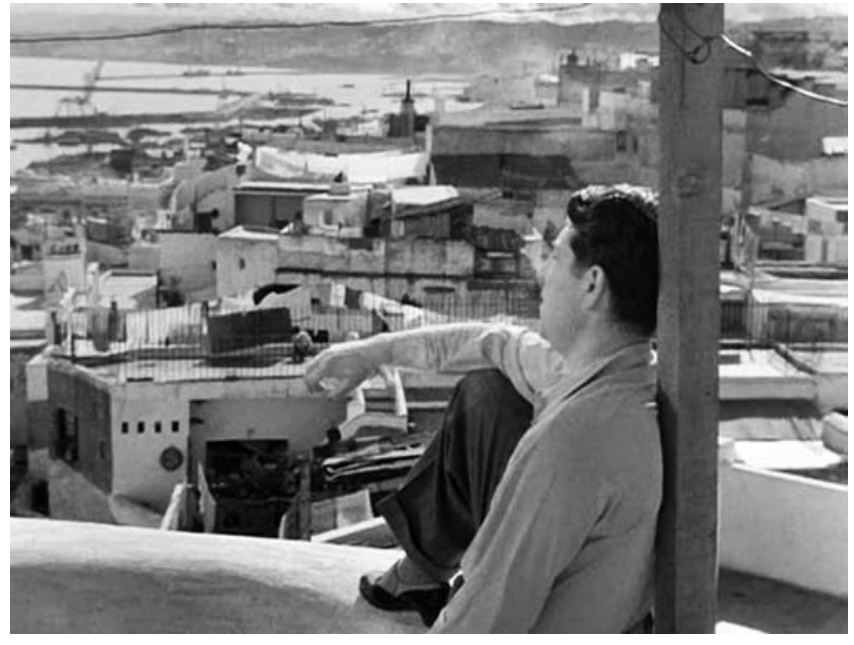

Jean Gabin surveys the Casbah in Pépé le Moko (1937).

following the loss of its colonies. By including such a detail, Battle can be seen to point forward in time to the postimperial as well as to the postcolonial, not only in the former colony of Algeria, but in the newly former metropole - that is, on the territory of France itself.

\section{The Battle for Housing}

The six-minute coda to Battle shows street protests and confrontations with soldiers and police, as well as the journalists that report them, taking place in December I960, three years after the events (the "battle") that constitute the bulk of the film storyline. ${ }^{27}$ What the film shows in the coda are protestors attempting, as Jim House notes, "to take the argument [about independence] to the Europeans" by leaving the areas where they were forced to live and moving into the European zones. ${ }^{28}$ The "flow" of Muslim Algerians from the areas allotted to them reverses the direction of flow seen both under the film's opening titles and later during the 
sequence of the general strike, when French soldiers storm the Casbah in imposing numbers. ${ }^{29}$ Notably, though, it also reprises the flow and purpose of the Algerian crowd that attempted, in an earlier scene, to leave the Casbah in order to protest the bombing by the French of Casbah homes, only to be halted not by the French but by officials of the FLN itself, who promise to "avenge" the people.

In the coda, the flow of the people is shown to elude and exceed FLN command, as the protests take on a joyous and carnivalesque aspect, beyond the control of any single authority (the absence of authority is emphasized in the coda voiceover). The reenactment of the demonstrations for the film takes place on the actual locations to the south and to the east of both the Casbah and downtown European city, the sites of the protests and encounters with the police and army just a few years previously. The Casbah is named in the voiceover, but seen only at night and only from outside and above. ${ }^{30}$ The coda's daytime images feature other locations and buildings entirely, ones which, as it turns out, have been much discussed by historians of colonial Algiers and by architectural historians (though not in relation to the film).

It is the urban history of Algiers itself that can clarify the character and significance of these locations. From the r 920 s on, the city experienced inward migration on a large scale so that the (Muslim) Algerian population grew in greater Algiers from about 70,000 in 1926 to nearly 300,000 by 1954, the year when the Algerian war of independence began. ${ }^{3 \mathrm{I}}$ The Algerian medina, the Casbah itself, became impossibly overcrowded, forcing newcomers into shantytowns seen by city and colonial authorities as potential hotbeds of criminality and nationalist sentiment. ${ }^{32}$ In response, then-mayor Jacques Chevallier initiated a project of "welfare colonialism" that constituted the first real effort to build mass social housing for Algerians. ${ }^{33}$ The mayor himself dubbed it the "battle for housing," a battle that overlapped with the military "battle" of Algiers itself and was similarly intended to ensure that Algeria would remain French. As he proclaimed: "France [has] to build in Algeria day and night, as much as possible, so that she [will] not have to worry any more about the political problem." ${ }^{34}$

The man chosen by Chevallier as his chief architect was Fernand Pouillon, already known for large-scale housing projects in Marseilles, the French port city seen as the metropolitan "twin" to Algiers across the Mediterranean. Pouillon built in a stripped-down classicist modernism that recalled the Italian rationalist architecture of the fascist period but was open to local influences. ${ }^{35} \mathrm{He}$ was commissioned by Chevallier to create three major housing projects in Algiers in the I950s, two of which, Diar El-Mahçoul and Climat de

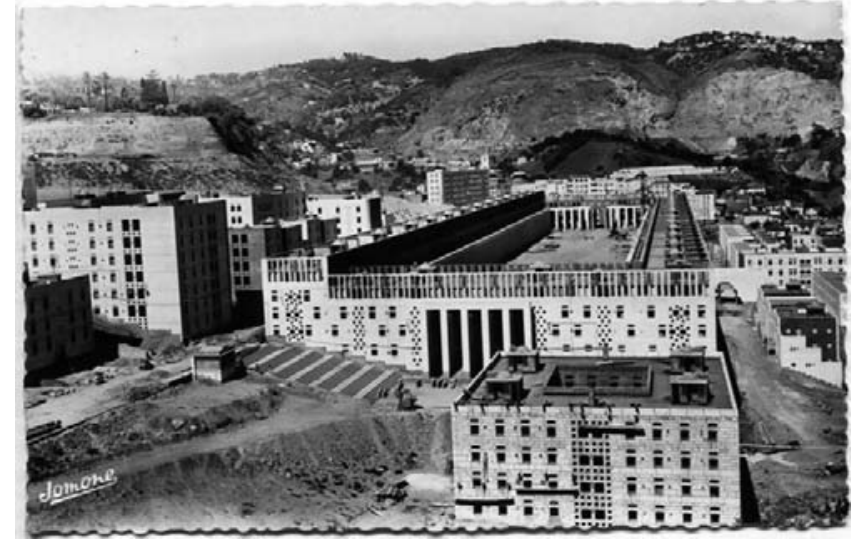

A postcard view of Climat de France under construction.

France, feature in the coda to Battle because both were sites of historic protests.

The Climat de France is the best known of Pouillon's Algiers projects, renowned for the edifice at its center: the 200 Columns, a vast rectangular housing block on a sloping site, with shops and facilities along the interior perimeter of a monumental agora. In his memoirs, Pouillon wrote of designing a monument to be lived in (the 200 Columns building), one that would ennoble Algeria's Muslim inhabitants who previously had been subject only to disdain and prejudice. ${ }^{36}$ However, historians of colonial architecture have argued to the contrary that his designs were intended to effect a cultural change on the native population. ${ }^{37}$ They were a form of what was called at the time "evolutionary" housing, a term that communicated the aim of transforming the rural Algerian migrants into modern Europeanized city dwellers. ${ }^{3}$ The irony is that it was precisely from within a housing project intended to acculturate and pacify the Algerians that the nationalist protests of December I960 emerged. The Algerians may have lived inside the buildings of the Climat de France, but they rejected the designs that its architecture had upon them.

How essential is the knowledge of the housing project's history for a viewer of Battle? While someone from Algiers would be aware that these coda scenes are set in locations with a very particular character and history, I suspect that the power of Battle's closing sequence and the sense of euphoria it communicates are fully shared by viewers not versed in the architectural context of colonial Algiers. ${ }^{39}$ To be sure, the sequence's power derives from a number of filmic elements working together through a culmination of audio, visual, and thematic strands that have been developed throughout Battle (most obviously, the sense of release expressed in the flow of the people after their domination and 

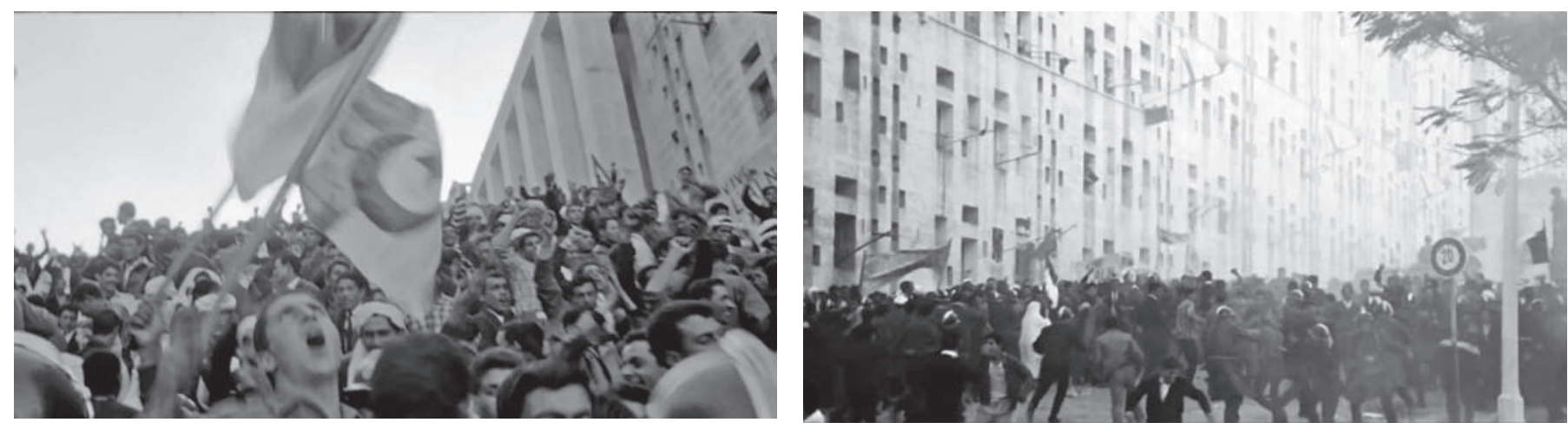

The 200 Columns building becomes the backdrop to the people's struggle.

containment in the rest of the film). However, the coda's formal representation of the Climat de France buildings and the structures they impose on its representation do echo the mise-en-scène and framing of the buildings and elevations seen earlier in the film, contributing to the power of this ending.

Here, the first thing to notice is what is not provided. The edifice shown in these images is the 200 Columns building, but what might seem an irresistible image of the $200 \mathrm{Col}-$ umns from above, or even of its famous courtyard, is not included. The film refuses the aerial shot that would express the monumentality envisaged by Pouillon and refuses an overview like that which establishes the opposition between European city and Casbah early in the film. The scenes play out, instead, at and near the bottom of the massive flight of steps at the eastern corner of the building. The camera looks up at the fortress-like exterior walls of the 200 Columns (rather than down on the massive steps teeming with demonstrators). ${ }^{40}$

The depiction of the 200 Columns actually recalls the ways that other buildings in Battle have been captured by the camera. First, a low-angle image appears at the culmination point of a nine-second pan from left to right. It shows a steep flight of steps in the Casbah, in a narrow street that almost resembles a corridor as the tops of the buildings are not shown, where a line of Algerians are all facing away from the camera (except for one little boy) and against the walls and doors with their arms raised. French soldiers watch them, as one soldier searches the pockets of a dead Algerian man. The film cuts to a medium close-up of the boy gazing at the dead man, then returns to the low shot looking up at the tableau in the street, held for a further four seconds as the French soldier occupies the vertical center of the space. Windows and doors are shuttered and barred throughout: the houses of the Casbah present a sealed aspect that can be taken as both a sign of resistance and of occupation, as the
French repossess homes and shops associated with the FLN. The low viewpoint up a flight of steps is retained in the later Climat de France scenes, except that the 200 Columns building disgorges its occupants, no longer fearful of the guns of their oppressors, in a burst of exuberant movement.

A second example can be seen in the tilt of the camera down the exterior of a tower block that straddles a roadthe elevation filling the frame so that sky and building edges are not shown - to reveal one of a series of actions of the FLN targeting police and soldiers over the course of a day. The military action of the FLN pictured here before a modernist edifice is eventually "potentialized" in the coda by a collective celebration of the community that takes place before the equally imposing elevation of the 200 Columns building. In this earlier scene, the setting is the Aéro-Habitat building, a private residential development for Europeans designed and built (in the 1950s) by followers of the great French architect Le Corbusier. ${ }^{4 \mathrm{I}}$ The film's brief glance at the Aéro-Habitat opens another historical view into the architectural history of twentieth-century Algiers. Le Corbusier spent several years designing never-built visionary schemes for the colonial city, then seen as the appropriate place for radical experimentation to mark the centennial of French occupation (1930). Eventually a version of his ideas for Algiers would find built expression, not in Algeria but rather in the housing projects of the French banlieues, in an instance of colonial conditions being transported to the territory of the metropole.

A final example can be found in the Barberousse prison, an edifice located at the top of the hill across from the entrance to the south side of the Casbah, pictured in an early scene that telegraphically narrates the politicization of the film's Algerian protagonist, Ali La Pointe. In this scene, the imprisoned Ali peers at the execution of an FLN militant through the barred slit in the thick exterior wall of his overcrowded cell. A high-angle shot representing Ali's subjective 


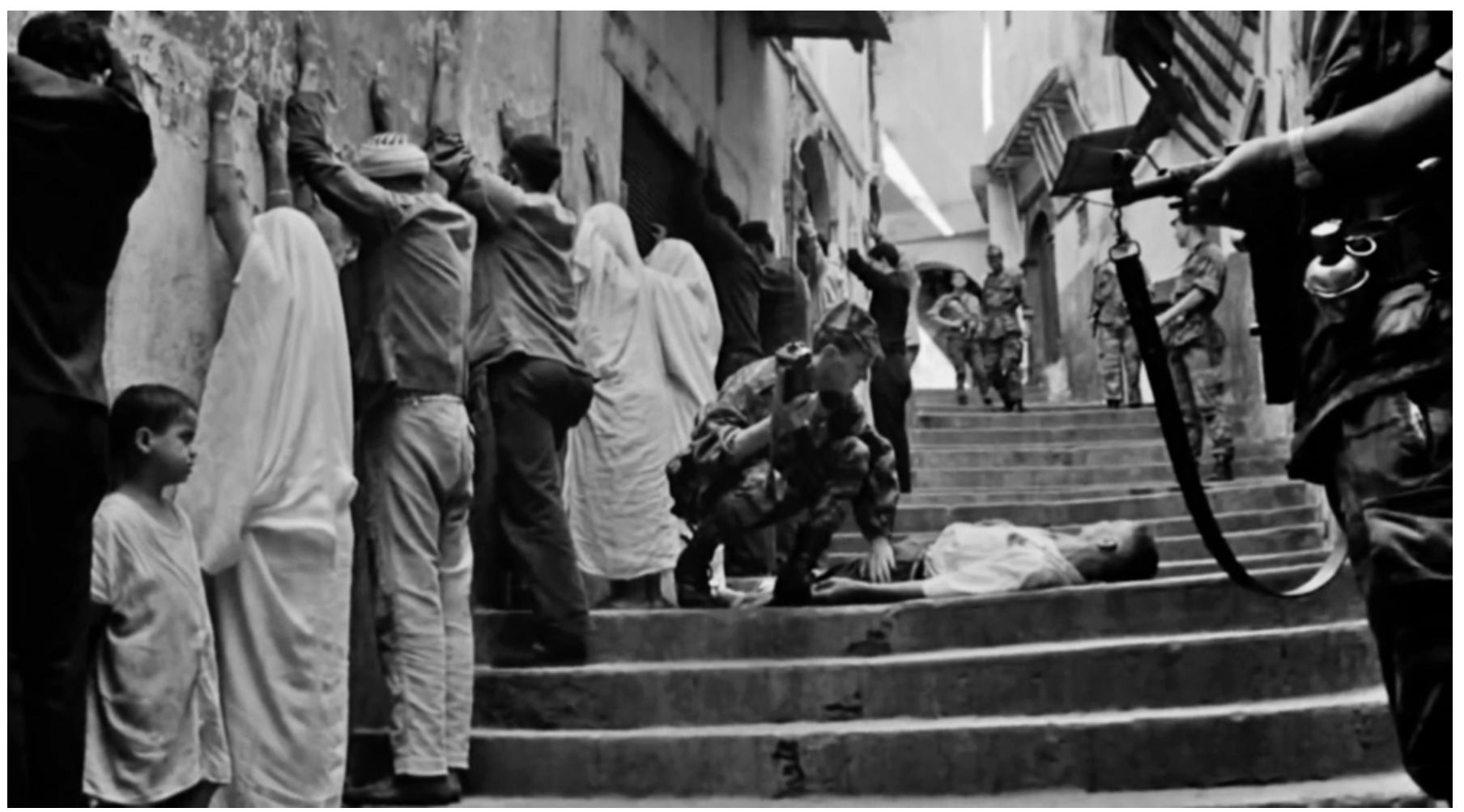

A death in a narrow street in the Casbah.

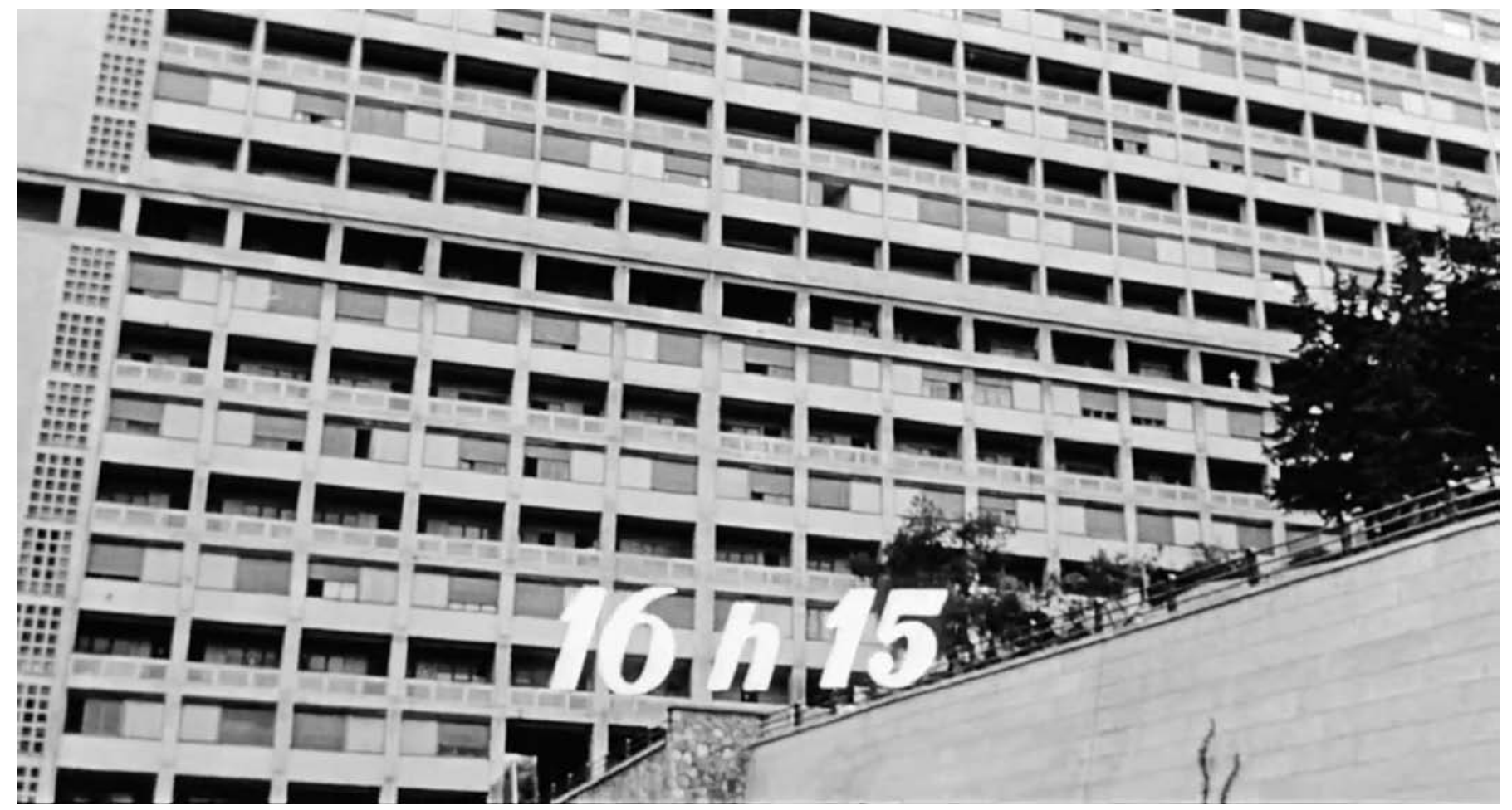

The Aéro-Habitat building. 


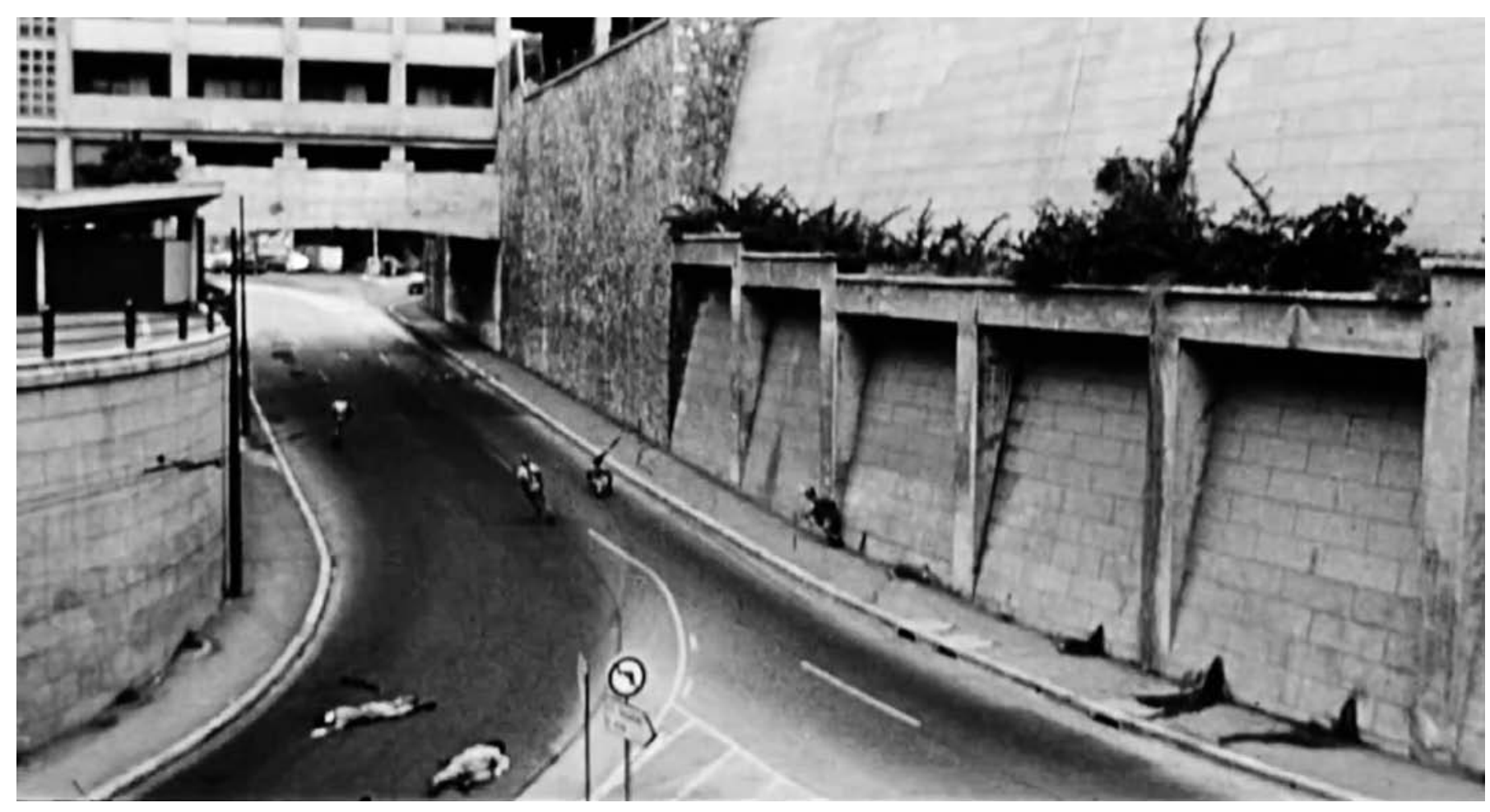

Aftermath of an FLN action at the foot of the Aerro-Habitat building.
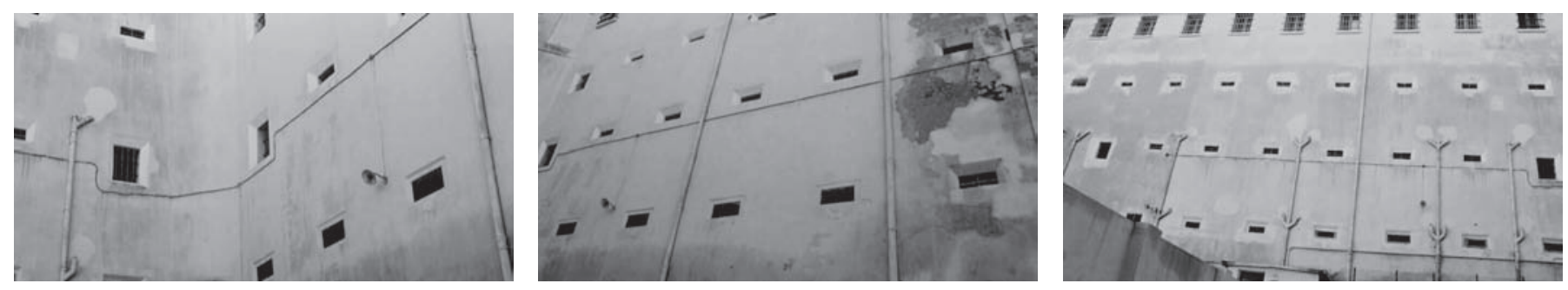

Three views of the Barberousse prison.

point of view looks down into the prison courtyard that contains a guillotine. The view then switches to a frontal framing and the camera's zoom onto the condemned man, followed by a panning shot that continues Ali's prior perspective. An extreme close-up of Ali's gazing eyes is followed by a cut to the guillotine and the activities of its hooded functionaries.

Of particular interest are the shots that follow: three static framings each lasting two seconds, each taken from a different position, but all gazing upward at the prison walls and windows, leading the viewer to assume that many other prisoners are, like Ali, staring out. The third of these framings is accompanied by the clatter of the guillotine, followed by the famous "crash-zoom" into another extreme close-up of Ali's gaze, which I take to signal the moment of his political awakening.
The exterior walls of the Barberousse prison with their small regular apertures (the barred windows) anticipate the thick walls and rhythmic fenestration of the 200 Columns building. Both buildings have been in different ways designed to "contain" the Algerians, and both house hundreds if not thousands of people. The difference is that the prison scene closes on the image of an individual still trapped behind barred windows, while in the coda sequence the Algerians as a social body emerge from the fortress-like Climat de France, dancing and chanting in carnivalesque protest. Though the coda's allusion is to newsreel photography, the erratic camera movement and disjunctive editing in the Climat de France scenes function as an aesthetic equivalent to the people's dance: the form itself is carnivalesque. The coda thus pictures the culmination of a process of politicization, of assuming historical agency, by what feels like an entire people, 
a process of transformation that escapes the boundaries of the architecture to erupt into the street and into history.

\section{A Third Space}

In positing an opposition between Casbah and European city, Battle proffers a kind of essentialism, one that elides the diversity of the groups that constituted colonizer and colonized in French Algeria. Among other things, it erases the particularity of the range of Mediterranean migrants who settled in Algeria; it ignores those native Algerians who fought for the French (the Harkis) and those members of the settler population who supported independence; it conflates different ethnicities and identities among the native population, implying that all Algerians are "Arab," thereby effacing Berbers and others, including a native Algerian Jewish population that was subject to attack by nationalists during the very events celebrated in the film. ${ }^{42}$ The film's essentialism is consistent with its status as a commissioned text presenting an FLN account of events, and is functional to its narrative economy and rhetorical power. But this binarism is violated in the coda when Battle pushes beyond the space of authenticity (the Casbah) and of occupation (the European city) to a third space that is hybrid and other to both.

Notions of a third space that retrospectively cast light on Battle's coda have been set out in distinct but related ways by Edward Soja and Homi Bhabha. ${ }^{43}$ Soja, a geographer and urbanist, intended the "thirdspace" to refer, in both a literal and metaphorical sense, to a combination of real and imagined spaces where it is possible to "respond to all binaries, to any attempt to confine thought and political action to only two alternatives. ... In this critical thirding, the original binary choice is not dismissed entirely but is subjected to a creative process of restructuring that draws selectively and strategically from the two opposing categories to open new alternatives." 44 Soja's "thirdspace," though conceptually elusive, can help to identify how the coda sequences, located temporally but also spatially beyond the main story, evince something new, unpredictable, hybrid.

For Homi Bhabha, on the other hand, all culture and all identity is hybrid, irreducible to an essence, and hybridity itself "is the 'third space' which enables other positions to emerge." 45 Bhabha's third space is a space of potential: "[It] displaces the histories that constitute it, and sets up new structures of authority, new political initiatives, which are inadequately understood through received wisdom." ${ }^{46}$ In the context of Battle, received wisdom might refer to the power/knowledge that underpins the colonial system and its brutal hierarchies, but it may also refer to any restrictive or prescriptive vision of a mono-ethnic, single-identity Algeria, as in the official FLN position regarding Algerian national identity: "Islam is our religion, Arabic is our language, Algeria is our fatherland." 47

The coda thus posits something that eludes and exceeds both the colonial wisdom and its reflecting double. This something, implicit in the interpellation of the viewer of Battle as witness to, even participant in, a history being played out (through the rhetoric of the film's realism), is described by Bhabha as an "international culture, based ... on the inscription and articulation of culture's hybridity." ${ }^{8}{ }^{8} \mathrm{He}$ argues that "it is the 'inter'- the cutting edge of translation and negotiation, the in-between space- that carries the burden of the meaning of culture. It makes it possible to begin envisaging national, anti-nationalist histories of the "people."'49 The coda's sequences show an oppressed people discovering a power that had been previously denied to them by the colonial occupier, but moving beyond any mere "representation" by an FLN leadership into a sense of agency held in common. These sequences also predicate a viewer, whoever $s / h e$ is and wherever or whenever $s /$ he is watching, who is invited to join the third space of utopian possibility, a space that emerges, for Bhabha as for Soja, as the "in-between," in the interstices or in the liminal. The coda to Battle is just such a space, a "beyond" to the story as narrated in the film and a threshold to the future for an ideally invigorated spectator poised to leave the cinema and enter history.

\section{The First Banlieue Film}

The future into which the spectator of Battle has always emerged is of course the postcolonial present, even when the spectator is stepping out of the theater into Old Europe. In closing, I return again to the idea of Battle as an end-ofFrench-empire film, recalling that the third spaces pictured in the coda hold a less utopian meaning: they anticipate the banlieues that materialize in France in the period following the loss of its colonies when migrants, especially from North Africa, begin to erect shantytowns beyond the periphery of large French cities. As Adrian Fielder writes, these new shantytowns "came to be perceived in the French media and political discourse as mini-casbahs inscribed on French soil, dangerous zones of indeterminacy into which the forces of law and order could not completely penetrate." ${ }^{\circ}$ In the mid-Ig6os, the shantytowns began to be replaced by mass housing complexes, which in turn have become home to the majority of immigrant families living in France.

As will be clear even from this brief description, France has undergone a process parallel to that which had earlier 


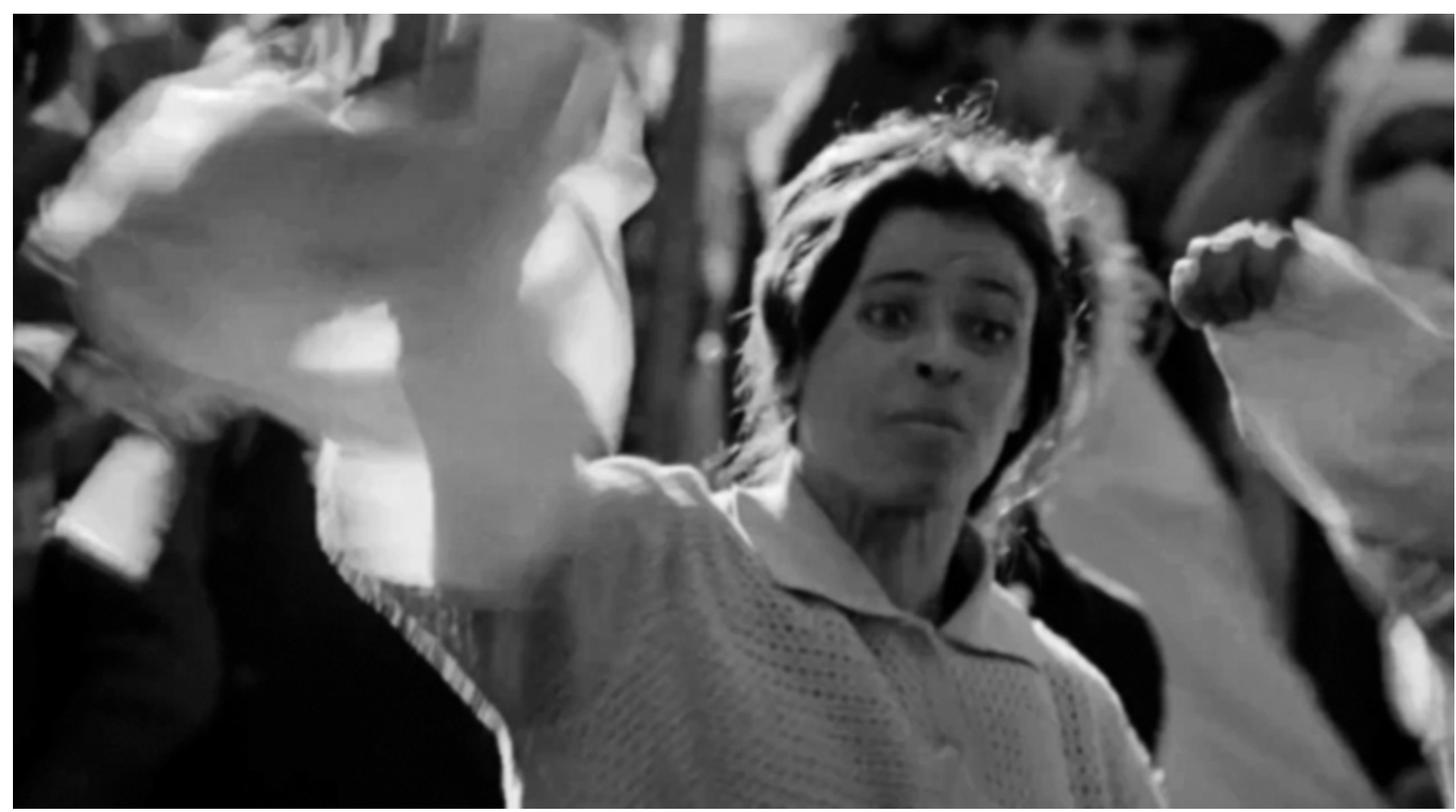

An Algerian woman celebrates a space of possibility.

taken place in Algiers: migration generated shantytowns, worries about security, and then building on a large scale to accommodate the newcomers. The French banlieues tend to have inadequate infrastructure and high unemployment and to be aggressively policed. As Fielder notes, the term banlieue designates a space "excluded" from the city even as it and its residents are subject to its jurisdiction. ${ }^{5 \mathrm{I}}$ Consequently, such districts have often been the site of protests and riots and, beginning in the 1980 , generated a version of social problem cinema which the Cahiers $d u$ cinéma has dubbed the "banlieue film," the best known example of which is La Haine (Hate, Mathieu Kassovitz, 1995). The banlieue film (defined like the western by its geographical location, as Will Higbee points out) typically employs a realist aesthetic that presents the "alienating architecture" of the housing estates to figure the marginalization of its young male protagonists. ${ }^{52}$ However, in this cinema, the meaning of the banlieue itself cannot be reduced solely to alienation because it also "remained the only real space of community and belonging." 53

The realistic mode, concern with space and place, and the ambivalent portrayal of location in films like La Haine and Ma 6-T va crack-er (Crack 6-T, Jean-François Richet, 1997) all link the banlieue film to the model of Battle. As Robert Stam and Ella Shohat have noted: "The visible checkpoints of The Battle of Algiers ... turn into the invisible barriers between banlieue and city center in the France of Mathieu Kassovitz's La Haine... . The footage of Parisian rebellions at the beginning of La Haine seems like a direct continuation of the demonstrations at the end of The Battle of Algiers. ${ }^{24}$ The sequences mentioned by Stam and Shohat constitute thresholds that allow ingress or egress to or from their respective films: they are liminal and supplementary sequences at once exceeding and essential to the narratives they launch or seal. ${ }^{55}$ Battle and La Haine, both made in black and white, have come to acquire a "semi-documentary status," even if there is a difference between the reenactment staged for the camera at the end of Battle and the archival footage recontextualized at the beginning of La Haine..$^{5}$ Another difference is that the footage in La Haine is conspicuously gendered male while the coda to Battle foregrounds veiled and unveiled Algerian women taking full part in the protests with the film closing on joyous but equivocal images of dancing women. ${ }^{57}$

That the "end" of Battle is still a (third) space of possibility that seems to be latent or lost by the time of La Haine confirms the accuracy of Gayatri Chakravorty Spivak's observation that "the future is always around the corner, there is no victory, but only victories that are also warnings." ${ }^{8}$ That future is named in voiceover to the coda to Battle, which announces that Algerian independence would come two years after the events shown, yet the coda also visually announces 
the persistence in urban space of Fanon's colonial world cut in two. In that sense, Battle adumbrates a hauntology of empire in the postcolonial period, a sense of a project still unfinished.

The partial origin of Battle in fascist colonial film suggests how a particular means to picture and "naturalize" the colonial scene can retain its power to picture the postcolonial scene. Homi Bhabha has argued that the colonial-era stereotype retains its "reality effect", just as the colonial representational mode retains its power to picture, because that is the mode in which cinema came to know the colonial condition in the first place. Obviously that argument is merely implicit here. The larger point, which may be controversial but bears repeating here in closing, is that Neorealism is not the sole point of origin of Battle. Its origins are far less straightforward and its legacy must therefore remain, today, more ambiguous.

\section{Editor's Note}

The new ${ }_{4} \mathrm{~K}$ fiftieth anniversary version of La bataille d'Alger was restored by Cineteca di Bologna and Istituto Luce - Cinecittà at L'Immagine Ritrovata laboratory, in collaboration with Surf Film, Casbah Entertainment Inc., and Cult Films, for theatrical release in the U.S. by Rialto. It debuted at the 2016 Toronto and New York film festivals. The 2004 DVD/Blu-ray box set continues to be distributed by Criterion Classics.

\section{Notes}

I. Nicholas Harrison, “Based on Actual Events': Pontecorvo's Battle of Algiers, 40 Years On," Interventions 9:3 (2007): 335-39, on 337 .

2. "La bataille d'Alger à présent," a special dossier in Cahiers du cinéma (September 2004): 64-74; B. Ruby Rich, "After the Fall: Cinema Studies Post-9/II," Cinema Journal 43:2 (2004): I09-I5. Rich asks: "What does it mean that in today's context The Battle of Algiers has begun to look like a recruiting film for Al-Qaeda?" (I I I). I use the ideological word terrorism without quotes in the text because the term itself is employed in Battle by one of the revolutionary leaders.

3. See, for example, Carlo Celli, Gillo Pontecorvo: From Resistance to Terrorism (Lanham, MD: Scarecrow Press, 2005).

4. Nicholas Harrison has assessed the "Islamic elements" in Battle and analyzed the problems in the critical discourse concerning these in "Yesterday's Mujahiddin: Gillo Pontecorvo's The Battle of Algiers (I966)," in Postcolonial Film: History, Empire, Resistance, ed. Peter Hulme and Rebecca Weaver-Hightower (London: Routledge, 2014), 23-46.

5. Amanda Crawley and Sophie Watt have recently pointed to how the lucidity of its presentation of counterinsurgency techniques, including those of "enhanced interrogation," meant that Battle came to be used as a training film for military and police internationally. "La bataille d'Alger or the Colonial Warfare at the Roots of a New World Order," paper presented at the symposium "The Battle of Algiers at 50: Legacies in Film and Literature," May i8, 2016, University of Sheffield. Even Edward Said, a great admirer of Battle, worried in an interview with Pontecorvo that the director might admire the imperialists he portrayed. See “The Quest for Gillo Pontecorvo," in Reflections on Exile and Other Essays (Cambridge, MA: Harvard University Press, 2000), 282-92.

6. See Michael O'Reilly, "The Return of the Battle of Algiers in Mediterranean Shadows: Race, Resistance and Victimization," California Italian Studies I:I (2010), available at http:// escholarship.org/uc/item/3nf4vorj

7. See Patricia Caillé, "The Illegitimate Legitimacy of The Battle of Algiers in French Film Culture," Interventions 9:3 (2007): 37I-88; and David Forgacs, "Italians in Algiers," Interventions 9:3 (2007): 350-64. Thanks to David Forgacs for generously commenting on a draft of this article.

8. See, for example, Peter Sainsbury, "Editorial," Afterimage 3 (I97I): 4-7.

9. See Nicholas Harrison's bibliography of material on the film available (for a fee) at www.oxfordbibliographies.com/view/ document/obo-9780I9979 I286/obo-9780 I9979I286-o I40.xml

Io. The Torino museum holds a range of important collections, several dedicated to Italian directors of the sixties and seventies like Elio Petri, Francesco Rosi, and Pontecorvo himself. The Pontecorvo archive has yet to be catalogued, but I have been able to consult it thanks to the generosity of archivists Carla Ceresa and Mauro Genovese. Several folders of material pertain to Battle or to Parà, the unfilmed script that predates Battle, also dedicated to the Algerian war and developed by Pontecorvo and his scriptwriter Franco Solinas with the producer Franco Cristaldi.

I I. For a summary of some of the criticism of the film in these terms, see Nancy Virtue, "Poaching within the System: Gillo Pontecorvo's Tactical Aesthetics in The Battle of Algiers," Screen 55:3 (2014): 317-37.

I2. I have not seen a copy of the film with this title intact, but it is recorded in a contemporary review by Maurice Rapf entitled "High Drama in a History Restaged," Life Magazine, October 27, 1967. For the often-retold story of how the film stock was treated in order to achieve the newsreel effect, see Irena Bignardi, "The Making of The Battle of Algiers," Cineaste 25:2 (2000): I4-22, on I9-20.

I3. Virtue, "Poaching within the System," 3 I8.

I4. Forgacs writes that "the film that Pontecorvo made in Algiers in 1965 was, in a loose sense, a remake of Roma città aperta twenty years later," though he warns that "one should push the analogy only so far" ("Italians in Algiers," 362).

15. Ruth Ben-Ghiat, Italian Fascism's Empire Cinema (Bloomington: Indiana University Press, 2015). With the phrase "end of empire," I am also thinking of work on architecture in Algiers that informs my account in this article: Sheila Crane, "Architecture at the Ends of Empire: Urban Reflections between Algiers and Marseille," in The Spaces of the Modern City: Imaginaries, Politics and Everyday Life, ed. Gyan Prakash and Kevin 
M. Kruse (Princeton, NJ: Princeton University Press, 2008), 99-I43.

I6. See Ruth Ben-Ghiat, "Fascism, Writing, and Memory: The Realist Aesthetic in Italy, I930-1950," Journal of Modern History 67:3 (1995): 627-65, and "The Italian Colonial Cinema: Agendas and Audiences," Modern Italy 8: I (2003): 49-63. Marie-France Courriol has traced debates in the r $930 \mathrm{O}-4 \mathrm{OS}$ concerning the cross-fertilization of documentary and fictional realism in Italian empire cinema set in Africa or the territories occupied by Italy in South Eastern Europe. See Courriol, "Documentary Strategies and Aspects of Realism in Italian Colonial Cinema (I935-I939)," Italianist 34:2 (2014): I22-4I.

I7. Evidently, there is something to be said about how Battle might be dealing in a cryptic or displaced way with the legacy of Italian colonialism. Rhiannon Noel Welch has already pointed this out in "Contact, Contagion, Immunization: Gianni Amelio's Lamerica," in Italian Mobilities, ed. Ruth Ben-Ghiat and Stephanie Malia Hom (London: Routledge, 20I6), 68-87, on 84n. Lucy Riall has recently argued that it is important to consider Italian colonialism beyond Italy's "official” colonies ("The Global Turn in Modern Italian History: Perspectives and Comparisons," plenary paper at the Society for Italian Studies interim conference, Trinity College Dublin, April 30, 2016). Many European migrants to Algeria were Italian, and these Italians were in a sense "colonialists": Battle can also be read to be dealing with their history, and to be alluding, however obliquely, to the fascist fantasy of "an imperial-diasporic nation that encompassed Italians in [Italy's] colonies, the metropole, and in Italian communities abroad" (Ben-Ghiat, Italian Fascism's Empire Cinema, xvii).

I8. As Ben-Ghiat writes, a definition of realism from 1933 by the avowedly fascist writer Elio Talarico, "a need for commitment, humanity, for a true sense of things and a concrete vision of the world," is identical to definitions to be found in left-wing theories of realism after I945. It is by now well accepted, at least within Italian Studies, that (to quote BenGhiat once again) "works such as [Rome Open City], which are often viewed as a stylistic rupture with the culture of fascism, may be better considered as the products of a decade of experimentation and debates over the realist aesthetic" (Ben-Ghiat, "Fascism, Writing, and Memory," 653, 660).

I9. Courriol, "Documentary Strategies," I28.

20. A comparison could usefully be made of the coda of Battle and the exuberant crowd scenes that close the Italian empire film Bengasi (Augusto Genina, I942).

2I. Guy Austin, Algerian National Cinema (Manchester: Manchester University Press, 2012), 37.

22. Frantz Fanon, "Concerning Violence," in The Wretched of the Earth (New York: Grove Press, I963), 35-1o6, on $3^{8 .}$

23. Mary Jean Green, "Echoes of the Casbah: From Pépé Le Moko to Bab El-Oued City," Nottingham French Studies 46:I (2007): 68-83.

24. Even the French military operation to defeat the FLN in Algiers is christened "Operation Champagne."

25. In thinking of the spatial oppositions in Battle in terms of rhetoric, I am following David Forgacs in "Space, Rhetoric, and the Divided City in Roma città aperta," in Robert Rossellini's Rome Open City, ed. Sidney Gottlieb (Cambridge: Cambridge University Press, 2004), Io6-30. Forgacs's analysis (building on Michel de Certeau) of the vertical and horizontal dimensions of the city in Rossellini's film has obvious applications to Battle, as Forgacs himself hints in his previously mentioned article "Italians in Algiers."

26. The film reprises a long-standing policy by the FLN to present their struggle at the international level. For an account of how the Algerian war of independence was also a war for international opinion waged between the French and the FLN, see Matthew Connelly, "Rethinking the Cold War and Decolonization: The Grand Strategy of the Algerian War for Independence," International Journal of Middle East Studies 33:2 (200I): 22 I-45. The character of the film's multiple address has yet to be thoroughly analyzed, though Murray Smith touches on this theme in "The Battle of Algiers: Colonial Struggle and Collective Allegiance," in Terrorism, Media, Liberation, ed. J. David Slocum (New Brunswick, NJ: Rutgers University Press, 2005), 94-I Io.

27. Most commentators erroneously speak of the coda events occurring two years after the death of the FLN leader Ali La Pointe that ends the main body of the film, but Ali was actually killed in October 1957 and the coda takes place in I96o. Battle opens with an onscreen title with the place and year "Alger I957" and circles back to this date via the long flashback that constitutes the bulk of the film. The historical protests shown in the coda took place in response to rallies by pro-French hardliners against the visit of the French president Charles de Gaulle to Algeria in December i960. In the previous month, de Gaulle had stated in a televised speech that an Algerian republic would "one day exist" and with its own government. Interestingly, the film omits this context.

28. Jim House, "Colonial Containment? Repression of Pro-independence Street Demonstrations in Algiers, Casablanca and Paris, I945-1962," War in History 24 (2017). Sincere thanks to Jim House, my colleague at Leeds, for sharing with me his research on the December ig6o protests in advance of its publication.

29. I have placed the word "flow" in inverted commas because in this context it is a term that bespeaks Orientalism. Connelly has described how France tended to understand the Algerian desire for independence as solely to do with problems related to the growth of the Muslim population: "while Algerians endured gross economic and political equality, French social scientists insisted that demographic disparities explained the [Algerian] war and that only French-led development could address them" [Connelly's italics]. Political agitation, he argues, was therefore "depicted as a 'rising tide' or a river overflowing its backs — even by anticolonialists like the director Gillo Pontecorvo. His The Battle of Algiers ... deliberately pictured Algerians as a flooding river sweeping the French before them." Michael Connelly, A Diplomatic Revolution: Algeria's Fight for Independence and the Origins of the Post-Cold War Era (Oxford: Oxford University Press, 2002), xi. For Pontecorvo's use of the river metaphor, see Piernico Solinas, Gillo Pontecorvo's "The Battle of Algiers" 
(New York: Scribners, I973), I65-66. The employment of Orientalist metaphor and stereotypes is a dimension of Battle that has been noted but not yet adequately treated in terms of the film's address to the France and the colonizing North.

3o. The Casbah is heard, though, with chanting and the ululation sounds made by Algerian women emerging from it. As many have noticed, the aural dimension of the film carries a powerful charge. The protest sequences, especially those I discuss that take place at Climat de France, feature an echoey, "distressed" sound quality (as if recorded with rudimentary equipment) that is of a piece with the high contrast film stock and use of telephoto lenses.

3I. Robert Descloîtres, Claudine Descloîtres, and Jean-Claude Reverdy, L'Algérie des bidonvilles (Paris, I96I), 8I, cited in House, "Colonial Containment?"

32. House, "Colonial Containment?" It is said that in the I 950 o the Casbah held the world record for human density, with 70,000 people living in an area of twenty hectares, or about fifty acres.

33. See Kahina Amal Djiar, "Politics and Housing in I95os French Algiers." in The Politics of Making, ed. Mark Swenarton, Idea Troiani, and Helena Webster (London: Routledge, 2007), $3^{6-48 .}$

34. Chevallier speaking at the groundbreaking ceremony for the Diar El-Mahçoul housing project, quoted in Zeynep Çelik, Urban Forms and Colonial Confrontations: Algiers under French Rule (Berkeley: University of California Press, I997), I43.

35. Karen Pinkus has argued that Italian fascist-period architecture in L'Eclisse (Eclipse, Michelangelo Antonioni, I962) is employed to figure the incomplete process of decolonization on the territory of Italy itself. See Pinkus, "Empty Spaces: Decolonization in Italy," in A Place in the Sun: Africa in Italian Colonial Culture from Post-Unification to the Present, ed. Patrizia Palumbo (Berkeley: University of California Press, 2003), 299-320. The use of Pouillon's designs in Battle suggest to me an awareness of the Antonioni model (Battle also contains a telling allusion to Red Desert, ig64). Once again, this strongly suggests that Battle is also a film on the consequences and legacy of the Italian colonial experience.

36. Fernand Pouillon, Mémoires d'un architecte (Paris: Seuil, I968), 205. If my conversations with artists and others in Algiers are an indication, both Chevallier and Pouillon are recalled with a certain sympathy and admiration. Diar Es-Saada, Pouillon's first housing project in Algiers (intended solely for Europeans), came to be pictured on a bank note issued by the new Algerian state in I964. See Crane, "Architecture at the Ends of Empire," II7-ig.

37. See Djiar, "Politics and Housing in I 950 os French Algiers."

38. See Shiela Crane, "On the Edge: The Internal Frontiers of Architecture in Algiers/Marseille," Journal of Architecture I6:6 (20I I): 94I-73. Crane writes: "Evolutionary housing was built on the universalist assumption that all French subjects could become French citizens, even though the very notion of the 'évolué paradoxically fixed a rigid hierarchy defined by racial difference" (963).

39. Walking around the Climat de France with my camera on a visit to Algiers in December 2015 I was shouted at in Arabic by a group of local kids: "Built by the French, lived in by Algerians, photographed by foreigners." My sincere thanks to Algerian artist Amina Menia for showing me around the Pouillon developments.

40. There are no doors in the exterior walls of the 200 Columnsonly windows, flights of stairs, and monumental entrances to the courtyard; there is no individual access to apartments from the outside of the building.

4I. André Loeckx and Tom Avermaete, “Architecture ou Révolution': Critical Moderns and the Search for a New Urbanity in I95os Algiers," in Colonial Modern, ed. Tom Avermaete et al. (London: Black Dog, 2010), I70-87, on I73-74.

42. The Great Synagogue in the Casbah was sacked, its Torah scrolls destroyed and the walls painted with threatening slogans. See Martin Evans, Algeria: France's Undeclared War (Oxford: Oxford University Press, 2012), 287-88.

43. Homi K. Bhabha, The Location of Culture (London: Routledge, I994); Jonathan Rutherford, “The Third Space: Interview with Homi Bhabha," in Identity: Community, Culture, Difference, ed. Jonathan Rutherford (London: Lawrence and Wishart, I990), 207-2 I; Edward Soja, Thirdspace: Journeys to Los Angeles and Other Real-and-Imagined Places (Oxford: Blackwell, ig96).

44. Soja, Thirdspace, 5 .

45. Bhabha in Rutherford, "Third Space," 2 I I.

46. Ibid.

47. See John Ruedy, Modern Algeria, and edition (Bloomington: Indiana University Press, 2005), 224. Ruedy writes of the official FLN attitude to Algerian national identity furthermore that the FLN's "credo reflected in broad terms a sense of cultural identity shared by a great majority of Algerians. But it left unsaid the ways in which each of its statements was true. . . . Did the Algerian fatherland have room for non-Arabs? For non-Muslims?"

48. Bhabha, Location of Culture, $3^{8 .}$

49. Ibid., 38-39 (Bhabha's capitals).

50. Adrian Fielder, "Poaching on Public Space: Urban Autonomous Zones in French Banlieue Films," in Cinema and the City: Film and Urban Societies in a Global Context, ed. Tony Fitzmaurice and Mark Shiel (200I), 270-8I, on 27I.

5I. Fielder, "Poaching on Public Space," 27r. See also Ginette Vincendeau, La Haine (London: I.B. Tauris, 2005), I 7.

52. Will Higbee, "Re-Presenting the Urban Periphery: MagrebhiFrench Filmmaking and the Banlieue Film," Cineaste 33:I (2007): $3^{8-43}$, on 38. See also Vincendeau, La Haine, 20-23. Vincendeau writes: "Rather than a genre, one can at best refer to a cycle or a series of films linked by a location" (23).

53. Higbee, "Re-Presenting the Urban Periphery," 39.

54. Robert Stam and Ella Shohat, "Afterword: History, Empire, Resistance," in Postcolonial Film: History, Empire, Resistance, ed. Peter Hulme and Rebecca Weaver-Hightower (London: Routledge, 2014), 288-99.

55. I have in mind the "logic of supplementarity" described by Jacques Derrida (an Algerian Jew) in his discussions of Kant and Rousseau. See Niall Lucy, A Derrida Dictionary (Oxford: Blackwell, 2004), I35-4I. Vincendeau talks of the banlieue in French cinema as "a borderline, heterogenous space that is 
neither town nor country, and in some cases deserves to be called a no man's land." Vincendeau, La Haine, 22.

56. Vincendeau writes that the five-minute opening sequence of La Haine is distilled from dozens of hours of newsreel footage, though she notes that the opening and grainiest images of a young man shouting at police are likely to have been created for the film since they feature synchronized sound. Vincendeau, La Haine, 46.

57. The images of the dancing women that close Battle recall Eugène Delacroix's picturing of Marianne in the I830 painting "Liberty Leading the People," as well as the running Pina, the female protagonist of Rome Open City, in her famous death scene in Rosselini's film. Plainly, the realistic register of Battle is discarded for a traditional symbolism in these closing scenes, even as the resemblance to newsreel is retained in the coarse editing, use of long lens, and grainy film stock. (Pontecorvo himself worried about the breaking of the realistic illusion; see Solinas, Gillo Pontecorvo's "The Battle of Algiers," I74.) But the images also recall sensual Orientalist imagery, for example paintings of harem dancers by the Italian Orientalist painter Giulio Rosati, and the dancers' play with flags and veils recalls Orientalist portrayals of Salomé.

58. Gayatri Chakravorty Spivak in Mahasweta Devi, Imaginary Maps: Three Stories (London: Routledge, I995), xxv. 